\title{
Using of Microsatellites to Study the Genetic Polymorphisms of SRYm18 Region in Iraqi Sheep
}

\author{
Hawraa Al-Mohamadawi ${ }^{1}$, Asaad Y. Ayied ID 2 \\ ${ }^{1,2}$ Animal Production Department, College of Agriculture, University of Basrah \\ Corresponding Author: asaad.yheia@gmail.com
}

\begin{abstract}
Article history:
Received 16 April 2021

Accepted 6 May 2021

keyword : $Y$

chromosome, SRYm18, polymorphisms, microsatellite, Iraqi

sheep.
\end{abstract}

\begin{abstract}
The origin of animals is usually determined by their paternal genotypes of the genes on the $\mathrm{Y}$ chromosome. In addition to the genes and their polymorphisms in the genome of mitochondria that are inherited through dams. In view of the lack of studies focusing on the genes of the $\mathrm{Y}$ chromosome in the world and their absence in Iraq. The aim of the present study was to identify the multiple genetic polymorphisms of the SRYM18 gene in the Arabi and Awassi sheep raised in Iraq. The study was conducted in the Genetic Engineering Laboratories - College of Agriculture, University of Basra, as well as in the Basra Genome Laboratory. The amplification of the SRYM18 gene showed genetic polymorphisms and gave a gene segment of (103-880) bp. The number of alleles of the SRYm18 gene was 13 alleles in the Arabi and 16 alleles in the Awassi breeds. The equilibrium test showed that the two breeds were under equilibrium. The two breeds were identical with nine alleles, while the number of special alleles for the Arabi breed was two, while the Awassi breed was distinguished by five. The number of rare alleles reached 20, of which seven were of the Arabi breed, and 13 of them were of the Awassi breed. Mean expected heterozygosity was 0.6386 with nonsignificant Fis for Arabi breed (0.1541) but significant for Awassi breed (0.2213). Mean neutrality was close to lower bound (0.1721) and (0.1270) for Arabi and Awassi breeds respectively.

* The research is quoted from the master's thesis of the first researcher.
\end{abstract}

\section{Introduction}

The genetic diversity of farm animals has long been a subject of concern and has important implications for genetic improvement, breeding management and genetic resource conservation programs. Microsatellite markers are the most common markers used in the genetic characterization of sheep breeds (Tapio et al, 2010; Calvo et al., 2011). Sheep were examined mostly by maternal analysis of mitochondrial DNA inherited in modern sheep breeds to determine the genetic history of domestication (Tapio et al, 2006), as well as using some genes on the $\mathrm{Y}$ chromosome.

The mammalian $\mathrm{Y}$ chromosome is one of the smallest chromosomes in the genome and contains the male pseudogenes through which, with the unique SSR technique of the $\mathrm{Y}$ chromosomes, it is possible to understand, develop and maintain sex chromosomes in mammals (Ginja et al, 2009). Y chromosome represents about $2 \%$ of the total DNA in the cells (Genomic Research, 2020). It was used to trace the paternal lineage of a population and to understand differences in migration and genetic variation between males and females with the addition of advantages of small size, effective population, and low mutation rate are sufficient markers for the distribution of the haplotype of a population (Jobling and Tyler-Smith, 1995; Jin and Su; 2000; Underhill et al, 2000). In comparison with other chromosomes, the $y$ chromosome contains a limited number of genes. Perhaps the low genes number of $\mathrm{Y}$ is a result of the tendency of these genes to change during evolution since they are nowadays fragmenting of an ancient common ancestor with the X chromosome (Graves, 1995).

The $\mathrm{Y}$ chromosome is made up of five different types of non-heterochromatic, pseudo- (XTR) regions, X-transposed, X-degenerate and AMP 
(Skaletsky et al., 2003). In addition to the central chromosomes, the $\mathrm{Y}$ chromosome contains a large segment of heterochromatin of $31 \mathrm{MB}$ on an arm, which is more than half of its total length (Skaletsky et al, 2003). The four regions are all isochromatic in contrast to the heterochromatic (Hughes and Rozen, 2012; Skaletsky et al, 2003). The two pseudo regions of the $\mathrm{x}, \mathrm{y}$ chromosome contribute to the correct pairing and segregation in mitotic cell division resulting in sperms originating in the XDG regions (Hughes and Rozen, 2012; Skaletsky et al, 2003).

In view of the lack of studies focusing on the genes of the $\mathrm{Y}$ chromosome in the world and their absence in Iraq, the aim of the present study was to identify the multiple genetic polymorphisms of the SRYm18 in the Arabi and Awassi sheep raised in Iraq.

\section{Materials and Methods Ethical Approval}

Prior to sampling, the objectives of the study were explained to the animal owners in their local languages so that they could make an informed decision regarding giving consent to sample their animals. Government veterinary, animal welfare, and health regulations were observed during sampling of the populations analyzed here. The procedures involving animal sample collection also followed the recommendation of directive 2010/63/EU. Collection of blood samples was permitted by the Iraqi Ministry of Agriculture.

This study was conducted in the Genetic Engineering Laboratory, College of Agriculture, University of Basra, and the laboratories of the Iraqi company and the Basra National Genome Laboratory. Blood samples were collected from the Iraqi sheep breeds, 105 samples from the Awassi, and 75 and Arabi breeds. A $5 \mathrm{ml}$ of blood samples from each animal were collected from both breeds from Maysan (Al-Majar Al-Kabir District) and Basra (Karma Ali District) southern Iraq.

\section{Blood Sample Collection}

Blood samples ( $5 \mathrm{ml} /$ animal) were withdrawn from the jugular vein using a $10 \mathrm{ml}$ medical syringe after the jugular vein area was cleaned and sterilized with ethyl alcohol. Blood samples were injected into tubes containing an anticoagulant (Tetra Acetic-Acid-EDTA Ethylene Diamine). The samples were freeze-preserved at $-4^{\circ} \mathrm{C}$ until the DNA extraction process was performed.

\section{DNA Extraction}

DNA was extracted from blood samples of Iraqi sheep breeds, in the genetic engineering laboratory, using the kit provided by the American company Invitrogen and according to the instructions provided in the kit.

\section{PCR Product}

A fragment (106-145 bp) of the SRYm18 was amplified using two primers: Forward primer: F 5'GGC ATC ACA AAC AGG ATC AGC AAT -3' and Reverse primer: R 5'- GTG ATG GCA GTT CTC ACA ATC TCC T -3 (Meadows et al, 2006). The PCR amplifications were conducted in a $50 \mu \mathrm{l}$ volume containing $20 \mathrm{ng}$ genomic DNA, $25 \mu \mathrm{l}$ of Master Mix, $2 \mu \mathrm{l}$ each primer, $15 \mu \mathrm{l}$ free water. The amplification conditions were as follows: initial denaturation at $95 \mathrm{C}$ for $5 \mathrm{~min}$ followed by 35 cycles of denaturation at $95 \mathrm{C}$ for $1 \mathrm{~min}$, annealing at $56 \mathrm{C}$ for $1 \mathrm{~min}$, and extension at $72 \mathrm{C}$ for $1.5 \mathrm{~min}$, and then the final extension at $72 \mathrm{C}$ for $10 \mathrm{~min}$. The PCR products were electrophoresed on $2 \%$ agarose gel stained with ethidium bromide to test the amplification success.

\section{Preparation of Agarose Gel}

After preparing the gel basin, washing and attaching the comb at one end and placing the plastic pieces on the edges of the basin, the transfer is done on the agarose gel at a concentration of $1 \%$, i. e. dissolving $0.25 \mathrm{~g}$ of the agarose in $25 \mathrm{ml}$ of $10 \mathrm{x}$ TBE solution and put it in a beaker and then heating it by microwave for 3 minutes until the clear color of the mixture. After that, $1 \mu \mathrm{L}$ of Ethidium bromide dye is added, taking into account the well-shaking of the beaker for the purpose of homogeneity of the dye with the mixture. Then the gel is poured into the transfer basin and left for the purpose of hardening (Williams et al, 1990).

\section{Electrophoresis}

The success of DNA extraction is determined by the use of the agarose gel electrophoresis technique by submerging the migration gel basin in the main basin containing the 10x TBE transfer solution. Then the mixture is injected into the drill and after the completion of the injection process, the electrodes are connected to the power supply and the electric current is fixed at 80 volts and 56 milliamps. The gel is left until the Bromophenol blue dye flows from the drill to the other side and 
after the migration process is finished, the gel is checked in the data documentation device (Gel documentation) for observing DNA bands interfering with Ethidium bromide

\section{Statistical Analysis}

For SRYm18 microsatellites, allele frequency, private alleles, and locus diversity parameters (expected heterozygosity (He), observed heterozygosity (Ho), Hardy-Weinberg equilibrium (HWE), allelic richness (AR), and neutrality test were calculated using the POPGENE 1.32 software program (Yeh et al, 1999).

\section{Results and Discussion}

\section{Number of Alleles and their Frequencies}

Table 1 shows the number of alleles and their frequencies of the SRYM18 microsatellite in the Arabi and Awassi sheep breeds. Arabi breed exhibited 13 alleles and those of Awassi were 16. Allele frequency of Arabi and Awassi breeds ranged from $0.017-0.600$ and $0.007-0.573$ respectively. Allele frequencies in both breeds were $0.009-0.581$. This study is the first study that uses a marker from Y chromosome of Iraqi sheep. Therefore, all discussion will depend on different microsatellites other that of $\mathrm{Y}$ chromosome. The aim of researching microsatellites is to use their markers to measure animal genetic diversity in order to aid maintenance and management strategies, improve mating processes, and reduce inbreeding rates (Crispima et al, 2014).

\section{Similar, special and Rare Alleles}

Table 2 shows the number of similar and specific alleles for the Arabi and Al-Awassi breeds of the microsatellite sequences of the SRYm18 microsatellites. The number of shared alleles was 9 . and the number of special alleles was 2 and 5 for the Arabi and Awassi breed respectively. In light of the current study, it is evident that there is a genetic variation between the two breeds, and that the genetic variation that was found in the Awassi and Arabi breeds is expressed by the presence of special alleles.

Table 1. Allele number and frequencies of SRYM18 microsatellites of Arabi and Awassi breeds

\begin{tabular}{|l|c|c|c|}
\hline \multirow{2}{*}{ Allele number } & \multicolumn{3}{|c|}{ Frequency (number) } \\
\cline { 2 - 4 } & Arabi & Awassi & Both breeds \\
\hline 103 & - & $0.020(2)$ & $0.011(2)$ \\
\hline 110 & $0.017(1)$ & $0.029(3)$ & $0.022(4)$ \\
\hline 128 & $0.035(3)$ & - & $0.017(3)$ \\
\hline 143 & $0.050(4)$ & $0.020(2)$ & $0.033(6)$ \\
\hline 157 & $0.035(3)$ & - & $0.017(3)$ \\
\hline 173 & $0.035(3)$ & $0.020(2)$ & $0.028(5)$ \\
\hline 188 & $0.100(8)$ & $0.080(8)$ & $0.089(16)$ \\
\hline 194 & - & $0.020(2)$ & $0.011(2)$ \\
\hline 201 & - & $0.013(1)$ & $0.006(1)$ \\
\hline 215 & $0.017(1)$ & $0.013(1)$ & $0.011(2)$ \\
\hline 242 & - & $0.013(1)$ & $0.006(1)$ \\
\hline 254 & $0.040(3)$ & $0.013(1)$ & $0.028(4)$ \\
\hline 591 & $0.017(1)$ & $0.133(14)$ & $0.083(15)$ \\
\hline 610 & $0.017(1)$ & $0.013(1)$ & $0.011(2)$ \\
\hline 643 & $0.017(1)$ & $0.020(2)$ & $0.017(3)$ \\
\hline 764 & $0.017(1)$ & $0.020(2)$ & $0.017(3)$ \\
\hline 800 & $0.600(45)$ & $0.573(60)$ & $0.581(105)$ \\
\hline 880 & - & $0.0267(3)$ & $0.017(3)$ \\
\hline
\end{tabular}

Table 2. Number of shared, special and rare alleles for ASRYm18 microsatellites in both

\begin{tabular}{|l|c|c|c|}
\hline \multirow{2}{*}{ Breeds } & \multicolumn{3}{|c|}{ No. of } \\
\cline { 2 - 4 } & shared alleles & special alleles & rare alleles \\
\hline Arabi & \multirow{2}{*}{11} & 2 & 7 \\
\cline { 1 - 3 } Awassi & & 5 & 13 \\
\hline
\end{tabular}




\section{Heterozygosity and Homozygosity}

Table 3 indicates the genetic diversity of both studied breeds expressed as observed and expected heterozygotes. Heterozygotic genetic percentage of Arabi is greater than in Awassi $(0.5333$ and 0.5048 respectively). With regard to the expected genotypes, Arabi breed recorded nearly similar to that of Awassi either calculated (0.6305 and 0.6533 respectively) or by Nei's method ( 0.620 and 0.6522 respectively). Although the observed heterozygosity is nearly 0.50 ( 0.5333 and 0.5048 respectively, the inbreeding coefficient for Awassi breed is significant $(\mathrm{p}=0.027)$ and highly positive (0.2913). the value recorded by Arabi breed is positive but not significant (0.1212). the positive value indicate that the population is under inbreeding status as expected heterozygosity is higher than observed. Negative Fis values indicate heterozygote defects (Dixit et al., 2009; Ojo et al , 2018) as the observed heterozygosity is higher than expected. Heterozygote deficiency may result from the admixture of two breeds or more, which resulted in population sub-structure (Cerda-Flores et al, 2002; Muema et al, 2009). Population subdivision due to genetic drift, null alleles, and inbreeding are also factors to this deficiency (Hoarau et al , 2005). The results indicated that there is very low admixture between the two breeds. The change in the proportions of heterozygosity between the two breeds is due to the random mixing between them and the lack of selection for these groups. These results are similar to what was reached by $\mathrm{Al}-$ Barzinji et al (2011), who used different microsatellites of Iraqi sheep.

Table 3. Genetic diversity of Arabi and Awassi breeds for the SRYM18 microsatellites

\begin{tabular}{|c|c|c|c|c|c|c|}
\hline Breed & Ho & He & He (Nei) & Mean He & Fis & P-value \\
\hline Arabi & 0.5333 & 0.6305 & 0.620 & 0.6386 & 0.1541 & 0.100 \\
\hline Awassi & 0.5048 & 0.6533 & 0.6522 & 0.6386 & 0.2213 & 0.027 \\
\hline
\end{tabular}

Ho: observed heterozygosity; He: expected heterozygosity, Fis: inbreeding Coefficient.

\section{Neutrality Test}

The mean of the neutral $\mathrm{F}$ test for Arabi and Awassi breeds was 0.1721 and 0.1270 respectively (table 4), The average of the neutrality indicates an expansion in the size of the population, that the values for the two breeds are close, and that these values confirm the balance of the two breeds as shown by the Hardy equilibrium test. The mean values for both strains are closer to the lower bound than to the upper bound, reflecting the low frequency of most alleles in the two strains. The decrease in frequency is an indication of an approaching loss of these alleles and may lead to a decrease in the genetic variation between individuals resulting from the method of breeding that depends on the presence of small-sized flocks and an increase in the effectiveness of genetic drift with an increase in the effect of some mutations.

The observed alleles richness was 13 and 16 alleles for Arabi and Awassi breeds respectively. The lowest and the highest bound of F for Arabi is higher than that for the Awassi breed (0.077 and $0.0455 ; 0.680$ and 0.7592 respectively). As for the standard error of Arabi breed is less than that found in Awassi breed (0.0016, and 0.00025 respectively), and these values reflect the similarity of the allele frequencies in the Arabi breed more than in the Awassi breed. And that the variation in the frequencies of genotypes is a genetic variation among individuals of the same breed.

Table 4. Neutrality test for Arabi and Awassi breeds

\begin{tabular}{|c|c|c|c|c|c|c|c|c|}
\hline \multirow{2}{*}{ Breed } & \multirow{2}{*}{$\begin{array}{c}\text { No. of } \\
\text { alleles }\end{array}$} & $\begin{array}{c}\text { Observed } \\
\text { F }\end{array}$ & $\begin{array}{c}\text { Lowest } \\
\text { value of F }\end{array}$ & $\begin{array}{c}\text { Highest } \\
\text { value of F }\end{array}$ & $\begin{array}{c}\text { Mean of } \\
\text { F }\end{array}$ & $\begin{array}{c}\text { Standard } \\
\text { Error }\end{array}$ & \multicolumn{2}{|c|}{$\begin{array}{c}\text { Confidence } \\
\text { interval (95\%) }\end{array}$} \\
\hline Arabi & 13 & 0.3800 & 0.0770 & 0.6800 & 0.1721 & 0.0025 & 0.1117 & 0.2956 \\
\hline Awassi & 16 & 0.3428 & 0.0455 & 0.7592 & 0.1270 & 0.0016 & 0.0795 & 0.2299 \\
\hline
\end{tabular}

The neutrality test uses a measure of the likelihood that the breeds have undergone demographic events such as genetic drift or expansion of population size. The results of the study showed that the values are positive for all tests in most cases. This explains the partial signs of the sudden expansion as a widespread population increases within the boundaries of the region in an expanding geographical area (Bruford et al, 2003). 


\section{Conclusion}

In conclusion, the studied breeds shared more than half the alleles ( 9 alleles) of the SRYM18. Most the alleles existed with very low frequency (less than 0.05), which may explain the neutrality mean is close the lower bound as a result of genetic drift specially there is no systematic selection.

\section{Conflict of Interests}

The authors declare that the research was conducted in the absence of any commercial or financial relationships that could be construed as a potential conflict of interest.

\section{Acknowledgments}

The authors acknowledge the staff of the Genetic Engineering Laboratory/ College of Agriculture, University of Basrah for timely help with guidance and support, especially Dr. Jaffar Mohamed Awaid.

\section{References}

Bruford, M. W.; D. G. Bradley and G. Luikart. 2003. DNA markers reveal the complexity of livestock domestication. Nature Reviews Genetics, 4(11): 900-910 DOI:10.1038/nrg1203

Calvo, J. H.; Alvarez-Rodriguez, J.; MarcosCarcavilla, A.; Serrano, M. and Sanz, A. 2011. Genetic diversity in the Churra tensina and Churra lebrijana endangered Spanish sheep breeds and relationship with other Churra group breeds and Spanish mouflon. Small ruminant research, 95(1), 34-39.

https://doi.org/10.1016/j.smallrumres.2010.09.003

Cerda-Flores R.M., Villalobos-Torres M.C., Barrera-Saldaña H.A., Cortés-Prieto L.M., Barajas L.O., Rivas F., Carracedo A., Zhong Y., Barton S.A. and Chakraborty R. 2002. Genetic admixture in three Mexican Mestizo populations based on D1S80 and HLA-DQA1 loci. American J. Hum. Biol. 14(2): 257-263. https://doi.org/10.1002/ajhb.10020

Crispima, B. A., Oliveira Seno, L. O., Egito, A. A., Junior, F. M. V. and Grisolia, A. B. 2014. Application of microsatellite markers for breeding and genetic conservation of herds of Pantaneiro sheep. Electronic Journal of Biotechnology, 17:
317-321.

http://dx.doi.org/10.1016/j.ejbt.2014.09.007

Dixit S.P., Verma N.K., Aggarwal R.A.K., Kumar S., Chander R., Vyas M.K. and Singh K.P. 2009. Genetic structure and differentiation of three Indian goat breeds. Asian-Australasian J. Anim. Sci. 22(9), 1234-1240.

https://doi.org/10.5713/ajas.2009.80510

Ginja, C.; Telo da Gama, L., and Penedo, M. C. T. 2009. Y chromosome haplotype analysis in Portuguese cattle breeds using SNPs and STRs. Journal of Heredity, 100(2): 148-157. https://doi.org/10.1093/jhered/esn080

Graves, J. A. M. 1995. The origin and function of the mammalian Y chromosome and Y-borne genesan evolving understanding. Bioassays, 17(4): 311 320. https://doi.org/10.1002/bies.950170407

Hoarau G., Boon E., Jongma D.N., Ferber S., Palsson J., Van Der Veer H.W., Rijnsdorp A.D., Stam W.T. and Olsen J.L 2005. Low effective population size and evidence for inbreeding in an overexploited flatfish, plaice (Pleuronectes platessa). Proc. Soc. Biol. Sci. 272, 497-503. DOI: 10.1098/rspb.2004.2963

Hughes, J. F., and Rozen, S. 2012. Genomics and genetics of human and primate $\mathrm{Y}$ chromosomes. Annual Review of Genomics and Human Genetics, 13: 83-108. https://doi.org/10.1146/annurevgenom-090711-163855

Jin, L.; Su, B., 2000. Natives or immigrants, origin and migrations of modern humans in East Asia. Nat. Rev. Genet. 1, 126-133. https://doi.org/10.1038/35038565

Jobling, M. A.; and Tyler-Smith, C. 1995. Fathers and sons: The Y chromosome and human evolution. Trends in Genetics, 11(11): 449-456 https://doi.org/10.1016/s01689525(00)891441

Meadows J.R.S., Hanotte O., Dro“gemu“ ller C., Calvo J., Godfrey R., Coltman D., Maddox J.F., Marzanov N., Kantanen J. and Kijas J.W. 2006. Globally dispersed Y chromosomal haplotypes in wild and domestic sheep. Animal Genetics 37: 444453. 2052.2006.01496.x https://doi.org/10.1111/j.1365-

Muema E.K., Wakhungu J.W., Hanotte O. and Jianlin H. 2009. Genetic diversity and relationship of indigenous goats of Sub-Saharan Africa using microsatellite DNA markers. Livest. Res. Rural 
Dev.

Available

http://www.lrrd.org/lrrd21/2/muem21028.htm

National Library of Medicine. Genetics home reference: your guide to understanding genetic conditions. https://ghr.nlm.nih.gov/gene

Nei, M. 1973. Analysis of gene diversity in subdivided populations. Proc. Natl. Acad. Sci. U.S.A. 70: 3321-3323. https://doi.org/10.1073/pnas.70.12.3321

Ojo, O. A., Akpa, G. N., Orunmuy, M., Adeyinka, I. A., Kabir, M. and Alphonsus, C. 2018. Genetic analysis of Nigerian indigenous goat populations using microsatellite markers. Iranian Journal of Applied Animal Sciences, 8 (2): 287- 294. http://www.ijas.ir/

Skaletsky, H.; Kuroda-Kawaguchi, T., Minx, P. J., Cordum, H. S., Hillier, L., Brown, L. G., and. Chinwalla, A. 2003. The male-specific region of the human $\mathrm{Y}$ chromosome is a mosaic of discrete sequence classes. Nature, 423(6942): 825-837. https://doi.org/10.1038/nature01722

Tapio, M.; Marzanov, N.; Ozerov, M.; Ćinkulov, M.; Gonzarenko, G.; Kiselyova, T. and Kantanen, J. 2006. Sheep mitochondrial DNA variation in European, Caucasian, and Central Asian areas. Molecular Biology and Evolution, 23(9), 17761783. https://doi.org/10.1093/molbev/msl043

Tapio, M.; Ozerov, M.; Tapio, I.; Toro, M. A.; Marzanov, N.; Ćinkulov, M. and Kantanen, J. 2010. Microsatellite-based genetic diversity and population structure of domestic sheep in northern Eurasia. BMC genetics, 11(1), 76. https://doi.org/10.1186/1471-2156-11-76

Underhill, P. A., Shen, P., Lin, A. A., Jin, L., Passarino, G., Yang, W. H., and Ibrahim, M. 2000. $\mathrm{Y}$ chromosome sequence variation and the history of human populations. Nature genetics, 26(3): 358361. https://doi.org/10.1038/81685

Williams, J.G.K.; Kubelik, A.R.; Livak, K.J.; Rafalski, J.A. and Tingey, S.V. 1990. DNA polymorphisms amplified by arbitrary primers are useful as genetic markers. Nucleic Acids Research., $18 \quad$ (22): 6531-6535. https://dx.doi.org/10.1093\%2Fnar\%2F18.22.65

Yeh, F. C., Yang, R. and Boyle, T. 1999. POPGENE version 1.31 Microsoft Window-based Freeware for Population Genetic Analysis Quick User Guide. University of Alberta and Tim Boyle,
Center for International Forestry Research, USA. ftp://ftp.microsoft.com/Softlib/MSLFILES/HPGL. EXE 